\title{
PSYCHOTECHNOLOGY OF PERSONALITY SPIRITUAL AND MORAL DEVELOPMENT
}

\begin{abstract}
у статті розглянуто освітній цикл підготовки срахівця-психолога як певну психорозвивальну технологію. Показано, що профресійний розвиток психолога $є$ динамічною, процесуальною системою, в якій можна виокремити певні етапи. Створено теоретичну модель підготовки психолога-практика та виокремлено умови, котрі максимізують вплив освітнього середовища на розвиток духовних спроможностей студентства. Наведено результати діагностичних обстежень, які показали, що становлення духовної сфрери особистості студента визначається не лише віковими та індивідуально-особистісними особливостями, а й організацією і реальним наповненням освітнього процесу. Показано, що створений у вищому навчальному заклад освітній простір позитивно впливає на прочеси духовного становлення особистості майбутнього фрахівия, однак цей вплив недостатній для самореалізації майбутнього психолога як високодуховної особистості, а тому необхідні спеціально створені умови, спрямовані на фрасилітацію процесів духовного зростання: самопізнання, саморозуміння, саморозвитку та самоактуалізації. Вказано, що через самопізнання студент поглиблює свої уявлення про себе, створює власну систему самоконцептуальності, завдяки процесам самоосмислення у нього складається певна оцінно-пізнавальна система, глибина і точність переживання якої залежить від інтенсивності і рівня протікання процесів самоаналізу, чітке i розгорнуте планування власної поведінки, об'єктивна й реалістична оцінка досягнутих результатів створюють підгрунтя для успішної самоактуалізації та самопроєктування особистості. На основі теоретичної моделі підготовки майбутніх фрахівців-психологів виокремлено чотири блоки прочесів духовного зростання: самопізнання, саморозуміння, саморозвиток і самоактуалізацію та здійснено підбір форм і методичних засобів проведення тренінгових занять, спрямованих на активізацію духовного потенціалу особистості студента.

Ключові слова: психорозвивальна технологія, освітній цикл підготовки, професійний розвиток психолога, духовний потенціал особистості, освітній простір закладу освіти, процеси духовного зростання.
\end{abstract}

In the article, an educational cycle of training of a psychologist is considered as some psycho-developmental technology. It is shown that the professional development of the psychologist is dynamic processual technology in which certain stages can be distinguished. A theoretical model of training a psychologist-practitioner is created and conditions are defined that maximize the influence of the educational environment on the development of students' spiritual abilities. Results of the diagnostic examinations are given, which showed that the formation of the spiritual sphere of the student's personality is determined not only by age and individual personality but also by the organization and real content of the educational process. It is shown that created in higher educational institution an educational space positively affects the processes of spiritual formation of the future specialist, however, this influence is insufficient for the self-realization of the future psychologist as a highly spiritual person, therefore, specially created conditions are needed to facilitate the processes of spiritual growth: self-knowledge, self-understanding, self-development, and self-actualization. Through self-knowledge, the student is shown to deepen his understanding of himself, create his system of self-conceptuality, in which some situational, often accidental images of himself are integrated into a more or less holistic and adequate idea of his self.

Due to the processes of self-understanding a certain evaluative-cognitive system is formed, the depth and accuracy of which depends on the intensity and level of self-analysis. Clear and detailed planning of one's behavior, objective, and realistic assessment of the achieved results create conditions for self-actualization and self-design of personality. Based on the theoretical model of the future psychologists training, four blocks of spiritual growth processes have been identified (self-knowledge, self-understanding, self-development, and self-actualization) and the selection of forms and methodical means of conducting training sessions were carried out aimed at activating the spiritual potential of the student's personality, in particular through the development of self-awareness processes. Key words: psycho-developmental technology, educational cycle of training, professional development of a psychologist, spiritual potential of a person, educational space of an educational institution, processes of spiritual growth.
Інтеграція вищої освіти України в європейський освітній простір ставить нові вимоги до підготовки висококваліфікованого фахівця, який, окрім професійних знань, повинен володіти певними спеціальними здібностями та особистісними якостями. Йдеться про здатність прийняття адекватних рішень у нестандартних ситуаціях чи за умов дефіциту часу, про швидкість, адаптивність і самостійність у пошуку нової інформації, гнучкість, динамізм та креативність професійної поведінки. При цьому на другий план відходить проблема гармонійного узгодження світоглядних засад, ціннісних настановлень, духовних потреб особистості випускника.

Психологія - особлива царина знань, у якій особистісна психодуховна недосконалість фахівця знижує рівень його професійної май- 
стерності. Дієвість психологічної допомоги часто визначається не лише професійними компетенціями спеціаліста, рівнем розвитку його когнітивних, інтерактивних особистісних характеристик, а й екзистенційно-смисловими та духовними аспектами. Формування професійної майстерності психолога особливо інтенсивно відбувається у період навчання в закладі вищої освіти і супроводжується напруженою роботою над собою, над визначенням меж своїх спроможностей, водночас з винятково інтенсивним розгортанням процесів ціннісного самовизначення, рефлексивної самоактивності та духовного самопізнання.

Вивченню різних аспектів проблеми професійної підготовки і становлення майбутнього фахівця-психолога присвячено багато робіт [1-8]. Вагомі авторські концепції представлені в працях О.Ф. Бондаренка, Ж.П. Вірної, В.Г. Панка, О.П. Саннікової, В.А. Семиченко, Ю.М. Швалба, Н.Ф. Шевченко, Н.В. Чепелєвої, А.В. Фурмана, Т.С. Яценко та інших відомих українських психологів. Директор УНМЦ практичної психології і соціальної роботи НАПН України В.Г. Панок, аналізуючи наявні підходи до змісту, форм, методів підготовки психологів-практиків, виділив три основні їх напрями: розвиток професійних знань, умінь, навичок, компетентностей; формування професійної мотивації, позиції, ставлення до професії; формування особистісних рис і якостей (в основному тих, які інтегруються поняттям «соціальна компетентність»). Науковець наголошує, що «студент тільки тоді стає справжнім фахівцем, коли починає бачити світ очима психолога» [1, с. 138]. Попри ґрунтовний аналіз різних аспектів змісту професійної підготовки майбутніх психологів-практиків, бачимо, що питання екзистенційно-ціннісного і духовно спрямованого становлення їх як майбутніх професіоналів залишається практично не висвітленим (за винятком повновагомих розвідок Е.О. Помитіна, М.В. Савчина, А.А. Фурмана). А тому мета статті-розглянути повний освітній цикл підготовки фахівця-психолога як своєрідну психорозвивальну технологію, в якій можна виокремити певні етапи особистісного розвитку і конкретні процеси духовного зростання майбутнього фахівця.

Виклад основного матеріалу. Наше дослідження ґрунтується на визначенні проф. A.В. Фурманом освітнього процесу як дидактичної і водночас психорозвивальної технології підготовки висококомпетентного фахівця, що здійснюється за умов чотирьохетапної діяльності зі свідомістю і самосвідомістю молодої людини як суб'єкта, особистості, індивідуальності та універсуму впродовж усього ії навчання у закладі вищої освіти [2, с. 80-104].

Освітній цикл підготовки фахівця-психолога сутнісно моделюється як особлива психороз- вивальна технологія, яка складається з чотирьох етапів: інформаційно-пізнавального, нормативно-регуляційного, ціннісно-рефлексивного та духовно-самореалізаційного. Засадничою основою кожного з етапів $€$ різноспрямована паритетна діяльність студентів і викладачів від першого до п'ятого (шостого) курсу, яка «визначається інваріантно-нормативним психосоціальним змістом їхньої ділової обопільної навчальної взаємодії.., спричиняє ритмічну зміну процесів самосвідомості у єдності з актуалізацією різних (когнітивного, емоційно-оцінкового, учинково-креативного, спонтанно-духовного) компонентів Я-концепції викладача і студента.., почергово реалізує пізнавальний, соціальний, конативно-вчинковий і морально-духовний потенціал кожного з них, збагачуючи їх як значеннєво-смислову сферу (свідомість), так і психодуховне узмістовлення компонентів позитивної Я-концепції (самосвідомість)» [2, с. 92].

За час навчання у стінах закладу вищої освіти здійснюється повноформатна програма професійної підготовки майбутнього фахівця. Власне, йдеться про чітко скоординовану та визначену сукупність певних методів, засобів, способів, прийомів, процедур, операцій, які регламентують діяльність учасників освітнього процесу та визначають їх діяльність «як учинкову метасистему, що підпорядкована законам як причинно-наслідкової детермінації, так і чітко спроєктованого цільового зумовлення та ціннісно-смислового відліку» [2, с. 89].

Перехід від теоретичного аналізу професійної підготовки майбутнього психолога у закладі вищої освіти до розгляду реальних конкретних сторін зазначеного процесу передбачає певну сполучну ланку, якою виступає розробка оптимальної моделі й технології професійного становлення психолога, певна стратегія і тактика оптимального поступу до професійної готовності й професійного розвитку. При цьому слід врахувати такі позиції. По-перше, моделювання професійного розвитку психолога неможливо розглядати поза професійно зорієнтованою освітньою діяльністю, яка є провідною в такому віковому періоді і в ході реалізації якої здійснюється розвиток як професійно необхідних, так і духовно-моральних якостей особистості. По-друге, зазначена психотехнологічна модель професійного розвитку відображає не всі характеристики особистості й діяльності, а лише основні базові компоненти і є орієнтиром у дослідженні динаміки професійного й особистісного розвитку майбутнього психолога.

Аналіз наукових джерел з проблематики ефективної підготовки майбутнього психолога дав змогу створити теоретичну модель підготовки психолога-практика з розвиненим духовним потенціалом (табл. 1). При цьому 
слід врахувати, що, по-перше, професійний розвиток психолога є динамічною, процесуальною системою, в якій можна виокремити певні етапи, по-друге, професійне становлення майбутнього фахівця характеризується нелінійністю, здатністю до самоорганізації, по-третє, професійний розвиток психолога проявляється у нерозривній єдності внутрішніх і зовнішніх факторів.

Проаналізуємо особливості розгортання процесів духовного зростання студентів у повному освітньому циклі. Через самопізнання учасники освітнього процесу поглиблюють уявлення про себе, створюють власну систему самоконцептуальності, в якій окремі ситуативно-випадкові образи власного Я інтегруються у досить цілісне й адекватне уявлення про себе. Завдяки процесам самоосмислення складається певна оцінно-пізнавальна система, глибина і точність усвідомлення якої залежить від інтенсивності і рівня протікання процесів самоаналізу. Вивчення психологічних дисциплін практичного спрямування, позанавчальна виховна діяльність стимулюють такі внутрішні пласти самоусвідомлення, як саморозуміння $і$ самоставлення, які значною мірою визначають особливості поведінки людини в проблемних ситуаціях.

Принагідно зазначимо, що, одержуючи інформацію про ситуацію або про наявні міжособистісні стосунки, студент не просто володіє нею, але й певним способом упорядковує, структурує та вибудовує відповідно до свого бачення. Паралельно проходить інтенсивна робота з викристалізування і усистемлення свого внутрішнього світу. «Людина прислуховується до себе, до свого внутрішнього голосу, порівнює і розрізняє, перебуває у стані творення свого внутрішнього світу, робить його більш системним та ієрархізованим» [3, с. 172]. Відбувається активний процес самоідентифікаці особистості. Надбані уявлення спочатку виникають ситуативно, потім узагальнюються та формують самоставлення особистості. Чітке і розгорнуте планування власної поведінки у різних ситуаціях, усвідомлення перешкод, які можуть виникати на шляху досягнення наміченої мети, програмування своїх дій з урахуванням цих перешкод, об'єктивна й реалістична оцінка досягнутих результатів створюють умови для самоактуалізації та самопроєктування особистості.

Синхронне формування внутрішнього світу особистісних смислів та організація зовнішнього знання у формі культури приводить студентів до усвідомлення нескінченності і вічності світу, в певному місці і в часовому бутті якого вони перебувають. Самоаналіз, здатність до рефлексії, до погляду на себе ніби «збоку» спричиняє внутрішне налаштування на духовне осягнення сенсу власного життя й у такий спосіб особистої причетності до мудрого, святого, вічного у земному часопросторі, до духовного прийняття Всесвіту.

Зазначені процеси активно функціонують за умов створення відповідного соціально-психологічного освітнього простору. Результати діагностичних досліджень, які проводилося на базі кафедри психології та соціальної роботи Тернопільського національного економічного університету (дослідницьку вибірку становили студенти спеціальності «Психологія» ступеня вищої освіти бакалавр та магістр, загальний обсяг вибірки - 106 осіб) показали, що прослідковується тенденція підвищення рівня духовного потенціалу та морально-етичної відповідальності студентської молоді (від недостатнього та низького рівнів на I курсі до

Теоретична модель підготовки психолога-практика

Таблиця 1 з розвиненим духовним потенціалом

\begin{tabular}{|c|c|c|c|c|}
\hline \multirow{2}{*}{$\begin{array}{c}\text { Домінанти кре- } \\
\text { дитно- } \\
\text { модульного } \\
\text { освітнього } \\
\text { циклу (за } \\
\text { А.В. Фурманом) }\end{array}$} & \multicolumn{4}{|c|}{ ПОВНИЙ ОСВІТНІЙ ЦИКЛ ПІДГОТОВКИ ФАХІВЦЯ-ПСИХОЛОГА } \\
\hline & $\begin{array}{c}1 \text { курс } \\
\text { Інформацій- } \\
\text { но-пізнавальний } \\
\text { етап }\end{array}$ & $\begin{array}{l}2 \text { курс } \\
\text { Нормативно-ре- } \\
\text { гуляційний етап }\end{array}$ & $\begin{array}{c}\text { 3-4 курси } \\
\text { Цінніс- } \\
\text { но-рефлексив- } \\
\text { ний етап }\end{array}$ & $\begin{array}{c}\text { 5-6 курси } \\
\text { Духовно-саморе- } \\
\text { алізаційний етап }\end{array}$ \\
\hline $\begin{array}{l}\text { Провідні форми } \\
\text { психологічної } \\
\text { налаштованості }\end{array}$ & $\begin{array}{c}\text { Позитивне став- } \\
\text { лення до професії, } \\
\text { бажання домог- } \\
\text { тись успіху }\end{array}$ & $\begin{array}{r}\text { Спрямован } \\
\text { оволодіння } \\
\text { сійними зна } \\
\text { вміннями, к } \\
\text { тенціял } \\
\end{array}$ & $\begin{array}{r}\text { Усвідо } \\
\text { відповід } \\
\text { психол } \\
\text { результа } \\
\text { діяль } \\
\end{array}$ & $\begin{array}{c}\text { Саморефлексія } \\
\text { та професійна } \\
\text { ідентичність }\end{array}$ \\
\hline $\begin{aligned} \text { Доміну } \\
\text { духовн } \\
\text { ц }\end{aligned}$ & Духовні стани & Духовні процеси & $\begin{array}{c}\text { Духовні власти- } \\
\text { вості }\end{array}$ & Духовні тенденції \\
\hline $\begin{array}{l}\text { Механізми актуа- } \\
\text { лізації духовного } \\
\text { потенціалу }\end{array}$ & $\begin{array}{r}\text { Спонтанн } \\
\text { механізм } \\
\text { активності }\end{array}$ & $\begin{array}{c}\text { Рефлексивний } \\
\text { аналіз та самоза- } \\
\text { глиб-лення }\end{array}$ & $\begin{array}{c}\text { Самодистанцію- } \\
\text { вання }\end{array}$ & $\begin{array}{c}\text { Гармонізація пси- } \\
\text { ходуховної сфери } \\
\text { особистості }\end{array}$ \\
\hline $\begin{array}{l}\text { Процеси духов- } \\
\text { ного зростання }\end{array}$ & Самопізнання & Саморозуміння & Саморозвиток & Самоактуалізація \\
\hline
\end{tabular}


переважно середнього та високого - у студентів-магістрів), частково проявляється зниження прояву егоцентричної спрямованості студентів, водночас у $16,1 \%$ студентів проявляється яскраво виражена егоцентрична спрямованість і у 47,2\% - прагматична, що в загальному становлять 2/3 респондентів. Ці результати є досить тривожними, особливо враховуючи особливості їхньої майбутньої професії. Позитивним фактом є виявлене в результаті обстеження зростання кількості виборів змістом смислу життя соціальних ідуховнихцінностей устудентів старших курсів.

Водночас порівняння одержаних у результатітестуванняданих (методикиЕ.О.Помиткіна «Духовний потенціал особистості-1», «Духовний потенціал особистості-2», опитувальник типу спрямованості особистості практичного психолога Т.М. Данілової) з матеріалами спостереження та анкетування стосовно духовних цінностей студентської молоді засвідчило, що для першокурсників порівняно зі студентами старших курсів характерна слабка орієнтація у загальнолюдських цінностях, у поняттях добра та зла, відсутнє конкретне розуміння призначення своєї професії. Чверть досліджуваних (24,5\%) мають нульовий рівень сформованості морально-етичних цінностей, 31,1\% недостатній рівень. Тобто у 55,6\% студентів не сформована морально-етична сфера. Дослідження показало, що майже 24\% досліджуваних орієнтуються на егоїстичні смисли, зокрема бути незалежним і нікому не зобов'язаним, бути здоровим, насолоджуватися життям, що засвідчує певну духовно-психологічну незрілість опитаних. 37,7\% респондентів майже ніколи не переживали альтруїстичних емоцій, 31,1\% - не керуються у своїх вчинках моральною мотивацією, у 37,7\% - не сформовано або майже відсутнє почуття відповідальності за свої вчинки, 24,5\% - взагалі не аналізують складні в морально-етичному плані ситуації, практично не замислюються над ними, що свідчить про недостатній розвиток моральних, гуманістичних та екзистенційних складників духовності у студентів.

Аналіз одержаних даних дав змогу висловити припущення, що становлення духовної сфери особистості студента визначається не лише віковими та індивідуально-особистісними особливостями, а й організацією і реальним наповненням освітнього процесу, передусім його цілями, змістом, формами, технологіями, методами і засобами. Тому із числа студентів-психологів 1-5 курсів було сформовано експериментальну групу, з котрими проводилися спеціальні тренінгові заняття з метою актуалізації їхнього духовного потенціалу. Інші студенти склали контрольну групу.

Коротко вкажемо на особливості основних етапів психодуховного розвитку майбутніх фахівців-психологів у ході тренінгових занять. Підбір і використання методичних засобів і форм проведення тренінгу здійснювався згідно з теоретичною моделлю підготовки майбутніх психологів і системно охоплює чотири блоки процесів духовного зростання: самопізнання, саморозуміння, саморозвиток і самоактуалізацію.

Для активізації процесів самопізнання студентської молоді ми використовували: діалогічно-дискусійну форму взаємодії через використання методу бесіди, діалогу та групової дискусії. Використання бесіди було спрямоване на засвоєння учасниками знань здебільшого евристичним шляхом. Необхідною умовою його ефективності є достатній запас емпіричних знань, рефлексивних уявлень, життєвих спостережень в учасників обговорення. Ми застосовували такі види бесід: систематизуючу (узагальнення та систематизація знань, встановлення зв'язку між новими смислами і раніше зробленими висновками) та евристичну (сократичну) бесіду, спрямовану на розвиток творчого мислення, прагнення до знаходження істини. Як матеріал для обговорень використовували описані в літературі ситуації Кольберта.

Іншим важливим методом нерегламентованої вербальної інтеракції $€$ спонтанна групова дискусія. Функційний зміст зазначеного методу забезпечувався реалізацією прийомів аргументації, дебатів, софістики, евристики, котрі сприяють «ефекту генерації» в ході дискусії і, щонайважливіше, актуалізують формування знань-суджень духовно-морального спрямування в її учасників. О.І. Климишин зазначає, що, «формулюючи моральне судження в процесі моральної рефлексії, реалізуючи свою індивідуальну та особистісну позицію, учасники дискусії стають творцями власної духовності шляхом перетворення понятійних, почуттєвих знань у духовне знання, наповнення особистісним змістом та особистісною значущістю» [4, с. 43].

Другий блок методів був підібраний для активізації і розвитку процесів саморозуміння учасників тренінгу. Для цього ми використали метод рольової гри та метод психодрами. Відразу зауважимо, що ігрову форму ми обрали з огляду на її функційні властивості, щонайперше здатність викликати «радість свободи власного Я». Спільні особливості рольової гри і психодрами полягають у тому, що в обох випадках відбувається розігрування змодельованих ситуацій певної сюжетної лінії. При цьому відбувається проєктування духовних цінностей учасників тренінгової групи в сферу реальних взаємин та їх подальша реалізація у вчинкових діях. Таким чином, персоніфіковані духовні цінності стають психологічним засобом відкриття свого внутрішнього світу 


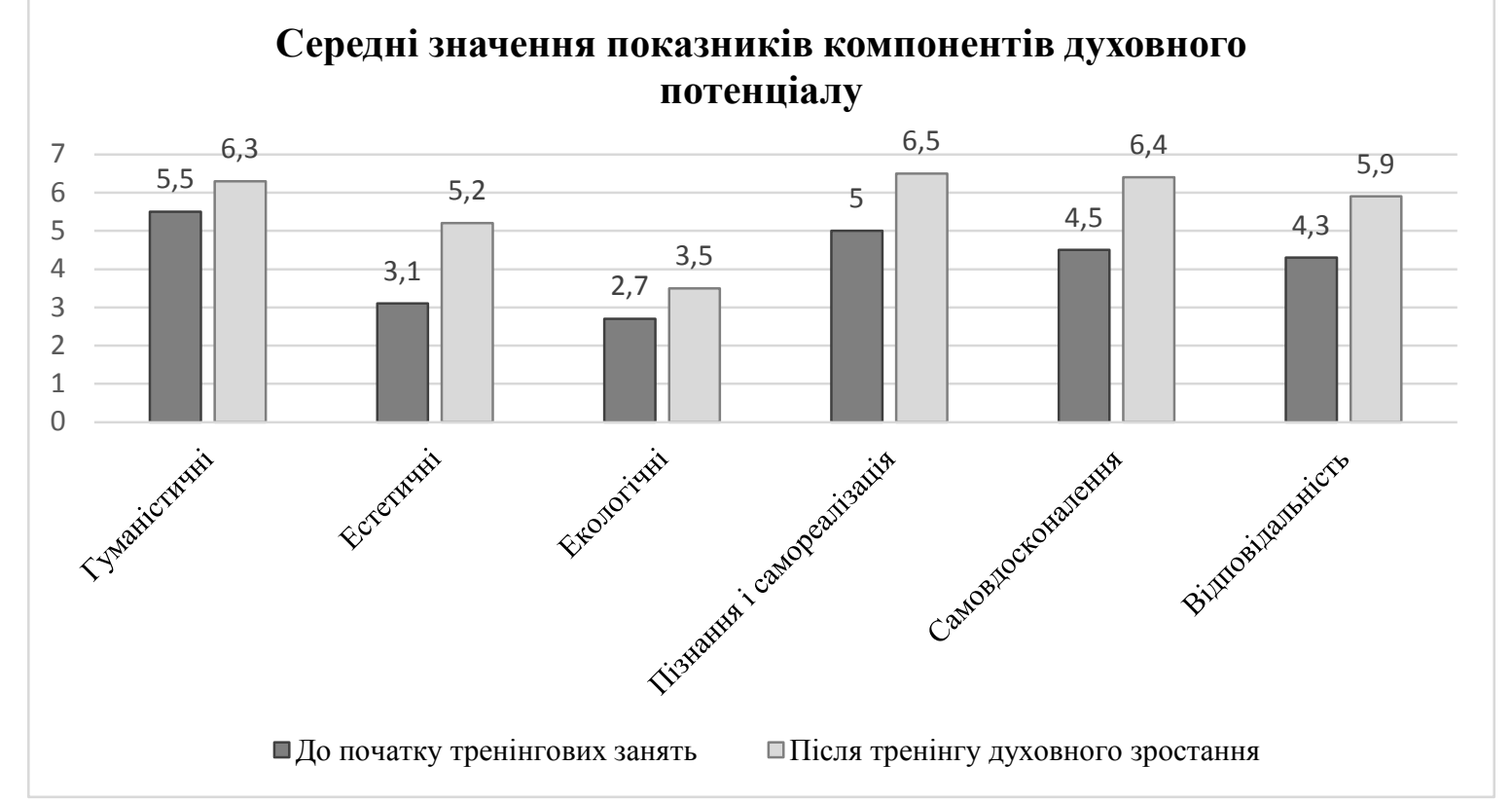

Рис. 1. Порівняльний аналіз показників компонентів духовного потенціалу студентів тренінгової групи за методикою Е.І. Помиткіна «Духовний потенціал»

іншим людям. Для програвання психодрами використовувалися такі техніки самопрезентації, виконання ролі, діалогу, монологу, дублювання, реплік у сторону, обміну ролями, техніки порожнього стільця, техніки дзеркала.

Наступний блок методів, які значною мірою пов'язані із стимулюванням внутрішнього саморозвитку учасників занять, забезпечувала реалізація невербально-інтроспективної формивзаємодії учасників тренінгу. З оглядуна те, що духовність - інтенційна та апріорна властивість людини, а її підґрунтя, за визначенням В. Франкля, - «несвідома духовність», ми підібрали методи, зорієнтовані на актуалізацію та експлікацію глибинних засад людської психіки, - психомалюнок та техніки естетотерапії.

Українська дослідниця, засновниця методу активного соціально-психологічного пізнання проф. Т.С. Яценко зазначає, що малюнок дає змогу людині у метафоричній, символічній формі презентувати свій внутрішній світ, свої життєві драми і цінності [5]. Тематика представлених учасниками тренінгу психомалюнків дає змогу зрозуміти ставлення людини до проблем власної екзистенції, а тому це створює можливості для «перепрограмування» іiї життєвого шляху. Ми використовували вільне, додаткове та спільне малювання. Специфіка нашого тренінгу визначала тематику психомалюнків. За основу було взято комплекс тематичних малюнків, запропонованих О.І. Климишин, і систематизованих відповідно до структурно-функційної організації духовного світу людини [4, с. 55-57].

Під час використання методів естетотерапії, зокрема методу рецептивної музикотерапії та пасивної арт-терапії, головний акцент зроблено на відомому розвитковому впливі музики та образотворчого мистецтва. Зауважимо, що кожен витвір мистецтва розпочинає своє функційне існування лише тоді, коли він стає об'єктом безпосереднього художнього сприймання.

Останній блок використаних методів був спрямований на підсумування одержаного в ході занять досвіду духовних переживань і пов'язаний 3 активним стимулюванням процесів самоактуалізації. Тут ми використали окремі елементи медитативних технік. На думку В.П. Москальця, «медитація - розумові зусилля людини, спрямовані на досягнення глибокої зосередженості її психіки, що $є$ передумовою самоспоглядання, самозаглиблення, самоаналізу тощо» [6, с. 232]. Особливого значення в ході нашого тренінгу мали медитації, під час яких відбувається візуалізація духовних цінностей - краси, добра, смислу, істини, гармонії. Такі медитації мають досить чітку алгоритмічну структуру, описану O.I. Климишин [4, с. 65-66].

Після закінчення тренінгу була проведена повторна діагностика духовного потенціалу особистості (за методикою Е.І. Помиткіна). Результати показали, що практично в усіх студентів тренінгової групи відбулось зростання основних показників духовного розвитку (рис. 1). Водночас у студентів, які не проходили тренінгових занять, показники залишились без змін.

Таким чином, підтвердилось припущення, що духовний потенціал студентів - майбутніх психологів актуалізується завдяки спеціально створеним умовам соціально-психологічного середовища, котрі спрямовані на фаси- 
літацію процесів духовного зростання: самопізнання, саморозуміння, саморозвитку та самоактуалізації.

Висновки 3 проведеного дослідження. Освітній цикл підготовки фахівця-психолога моделюється як особлива психорозвивальна технологія, яка складається з чотирьох етапів: інформаційно-пізнавального, нормативно-регуляційного, ціннісно-рефлексивного та духовно-самореалізаційного. Засадничою основою кожного з них є різнопланова паритетна взаємодія та безперервне коректне керівництво психодуховним розвитком особистості студента.

Відповідно до розробленої теоретичної моделіпідготовки фахівця-психолога розкрито психотехнологічні умови духовного зростання майбутнього психолога, що передбачають наявність специфічного соціально-психологічного середовища, спрямованого на фасилітацію процесів духовного зростання: самопізнання, саморозуміння, саморозвитку і самоактуалізації та підібрані відповідні методичні засоби і форми проведення спеціальних тренінгових занять.

Подальшого дослідження потребує вивчення механізмів духовного зростання студентів, зокрема особливостей протікання процесів самопізнання, самоосмислення, саморозуміння і самоставлення, котрі слугують основою для самоідентифікацї та самопроєк- тування особистості, дають змогу поглибити уявлення про себе і створити власну систему самоконцептуальності.

\section{ЛІТЕРАТУРА:}

1. Панок В. Профресійне становлення практичних психологів: досвід і перспективи. Психологія і суспільство. 2013. № 3. С. 135-141.

2. Фурман А.В., Надвинична Т. Психологічна служба університету: від моделі до технології. Психологія і суспільство. 2013. № 2. С. 80-104.

3. Савчин М. Здатності особистості : монографрія. Київ : ВЦ «Академія», 2016. 288 с.

4. Климишин O.І. Теорія і методика тренінгу розвитку духовності особистості. Івано-Франківськ : Нова Зоря, 2008. 112 с.

5. Яценко Т.С., Глузман А.В. Методология глубинно-коррекционной подготовки психолога. Днепропетровск : Изд-во «Инновация», 2015. 396 с.

6. Москалець В.П. Психологія релігії : посібник. Київ : Академвидав, 2004. 240 с.

7. Abramova I.V., Shilova Z.V., Varankina V.I., \& Rubanova I.V. Pedagogical Model of Integrative-Modular Training in Professional Preparation of Students. European Journal of Contemporary Education. 2019. No. 8(1). Pp. 187-200.

8. Ismail N., Sabapathy C. Workplace simulation: An integrated approach to training university students in professional communication. Business and Professional Communication Quarterly. 2016. No. 79(4), Pp. 487-510.

9. Ilyin $A$. The system of professional training of future teachers: Functional Approach. Revista San Gregorio, 2018. No. 23. Pp. 32-39. 